\title{
Britain faces up to transparency review
}

[LONDON] British academics are reacting warily to the prospect of increased paperwork and closer scrutiny of their activities as a result of the first wave of a 'transparency and accountability review' of research.

The review is being introduced into eight pilot universities following the government's comprehensive spending review last year. This made more money available to universities on condition that they accept increased public scrutiny of how the money is spent.

The Treasury-driven review requires universities to cost the activities of staff by department, subject and type of research sponsor. The government wants greater transparency of university research, on which it spends $\mathfrak{E} 1.7$ billion a year.

"Improving transparency is an important step in maintaining the health of university research," said John Taylor, director general of the research councils, last week. $\mathrm{He}$ was commenting on a report outlining how universities could implement a uniform approach to costing research.

Taylor promised that the methodology proposed would not impose "requirements that are unnecessarily burdensome". But the academic community is concerned it will mean more paperwork and closer scrutiny of spending decisions.

"Of course they are suspicious," says Robin Jackson, policy adviser for the Com- mittee of Vice-Chancellors and Principals. "This is an additional requirement on an overburdened and under-funded system." But he points out that it is "not an exercise to determine a shortfall in funding".

Heather Williams of the Higher Education Funding Council for England, and also a member of the steering group that commissioned the report, says the methodology "is simple to implement and gives reasonably robust, auditable figures without an administrative burden".

Some argue that the review cannot determine whether the full costs of research are being met by research funders, as they would like, as it fails to require reporting of the number of hours worked by academics.

"This is where people magic money out of thin air when they say the research base is well funded," says Peter Cotgreave, director of the lobby group Save British Science. "When the issue of full overhead costs for grants comes up, people say that, because the research is being done, there must be enough [money]. The truth is that people work longer hours to get it done."

There is concern that the transparency review could work against universities if it is found that teaching grants are being spent on research. But this seems unlikely, given the pressures on teaching resources within higher education. The recent expansion of stu-

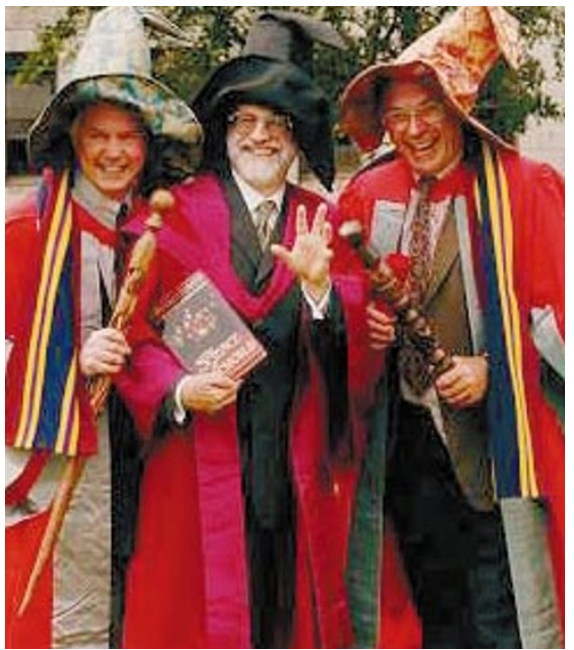

The novellist, Terry Pratchett (centre) has received an honorary degree at the University of Warwick for the science content of his 'Discworld' books. Ian Stewart (left) and Jack Cohen (right), his coauthors on The Science of Discworld (Ebury), were made 'honorary wizards of the Unseen University'.

dent numbers has already seen a decline in the resource allocation per student.

There will be a three-stage implementation of the proposals. New costing standards should be reported by January 2001 for eight pilot universities, and by summer 2001 for a further 30 universities.

NatashaLoder

\section{White House cool on obtaining human embryonic stem cells}

[WASHINGTON] The Clinton administration last week distanced itself from an impending recommendation by a presidential advisory commission that the government should fund both the derivation and the research use of human embryonic stem cells.

The recommendation is expected from the National Bioethics Advisory Commission (NBAC), which met in Cambridge, Massachusetts, last week to finalize a report to President Bill Clinton on the ethics of stem-cell research. The report may foment a Congressional debate that pits opponents of abortion against advocates of stem-cell research (see Nature 399, 292; 1999).

But the White House seems to be trying to avoid an open conflict. Advocates of stemcell research hope it will yield cell and tissue therapies for diseases such as Parkinson's and juvenile diabetes. Opponents decry the research because the derivation of stem cells requires the destruction of embryos.

In a statement issued after NBAC met, the White House press secretary said the administration "recognizes that human stem-cell technology's potential medical benefits are compelling and worthy of pursuit, so long as the research is conducted according to the highest ethical standards".

But the statement added an implicit repudiation of the NBAC's recommendation that the government should finance the harvesting of stem cells from embryos left over after fertility treatments. It said that no legal action is necessary now "because it appears that human embryonic stem cells will be available from the private sector".

If the administration were to embrace a recommendation that it fund the collection of stem cells, it would have to lobby Congress to overturn or liberalize a law that bans government funding of research in which embryos are destroyed or discarded.

The government position is that federal funds may finance research on stem cells but not their harvesting, which must be done with private funds. This was delivered in a decision by the legal counsel of the Department of Health and Human Services in January (see Nature 397, 185; 1999).

But the authors of the ban on embryo research contest this interpretation. They may try to rewrite the ban to apply explicitly to stem-cell research when the appropriations bill to which it is attached is finalized this summer. If they do so, it is not clear which side would prevail in Congress.

Frank Young, a commissioner of the Food and Drug Administration under Ronald Reagan's presidency, said: “To say, on the one hand, that you cannot support the deliberate destruction of living human embryos to harvest their stem cells, but that you will, on the other hand, pour millions of taxpayer dollars in support of research that you know can only take place using materials derived from that destruction, is an exercise in sophistry, not ethics." Young was speaking on behalf of a group of abortion opponents called Do No Harm: The Coalition of Americans for Research Ethics.

But Joseph Cerquone, a spokesman for the Patients' Coalition for Urgent Research, said his organization was "heartened" by the NBAC report and the White House reaction.

A spokeswoman for Harold Varmus, director of the National Institutes of Health, said last week that guidelines under which investigators funded by the agency may proceed with stem-cell work will soon be published. "We're being careful with them," she said, adding that they are already being discussed with the Department of Health and Human Services.

Meredith Wadman 